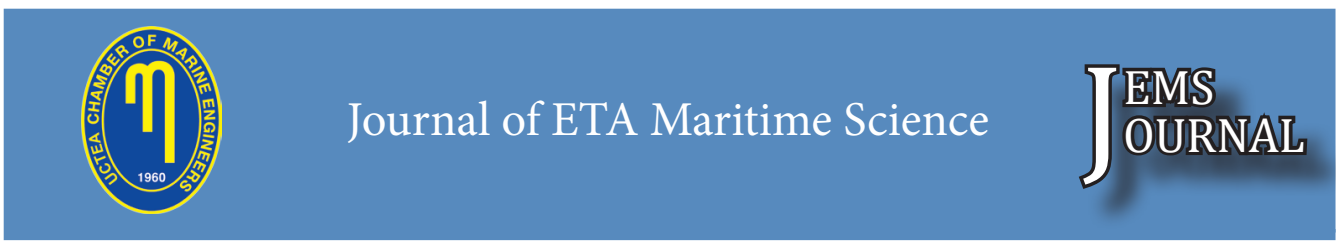

Corresponding Author: Abdullah AÇIK

\title{
Efficiency in Dirty Tanker Market
}

\section{Sadık Özlen BAŞER, Abdullah AÇIK}

Dokuz Eylül Üniversitesi, Denizcilik Fakültesi, Türkiye

ozlen.baser@deu.edu.tr; ORCID ID: https://orcid.org/0000-0001-6632-2617

abdullah.acik@deu.edu.tr; ORCID ID: https://orcid.org/0000-0003-4542-9831

\begin{abstract}
The maritime industry is highly capital intensive. From this point of view, it is very important that the return of the investments made is healthy. This can be achieved by efficiency of the freight market. The aim of this study is to contribute to the literature by testing the efficiency of the dirty tanker freight market used for the transportation of crude oil, which still has a great demand in the world economy, using an alternative test. In this direction, the daily values of the 1-year times charter rates of Aframax, Suezmax and VLCC ship types were used and the efficiencies of these three sub markets were tested using the Brock, Dechert and Scheinkman (BDS) independence test. The data set covering the years 2005 and 2017 and consisting of 663 observations per ship type on a weekly basis was used. As a result of the study, it is determined that the dirty tanker market does not exhibit random walk, in other words, does not have the characteristics of the Efficient Market Hypothesis (EMH), and that the time charter rates are related to their past values. This situation makes it possible to obtain excess profits using past data and some trading strategies.
\end{abstract}

Keywords: Efficient Market Hypothesis, Dirty Tanker Market, BDS Test.

\section{Kirli Tanker Piyasasında Etkinlik}

\section{$\ddot{O} z$}

Denizcilik sektörü oldukça sermaye yoğun bir sektördür. Bu açıdan yapılan yatırımların karşılı̆ğının sağlıklı bir şekilde geri dönmesi oldukça önemlidir. Bu da navlun piyasasının etkin olmasıyla sağlanabilir. Bu çalışmanın amacı, dünya ekonomisinde hala büyük bir talep gören ham petrolün taşımacılığında kullanılan kirli tanker navlun piyasasının etkinliğini alternatif bir test kullanarak test ederek literature katkıda bulunmaktır. Bu doğrultuda Aframax, Suezmax ve VLCC gemi tiplerinin 1 yıllık zaman kiralama bedellerinin günlük değerleri kullanılmıștır ve bu üç alt piyasanın etkinlikleri test edilmiştir. 2005 ve 2017 yıllarını kapsayan ve haftalık bazda her gemi türü için 663'er gözlemden oluşan veri seti kullanılmıştır. Veri seti Brock, Dechert ve Scheinkman (BDS) bağımsızlık testi kullanılarak analiz edilmiștir. Çalıșmanın sonucunda kirli tanker piyasasının rassal yürüyüş sergilemediği, başka bir deyişle Etkin Piyasa Hipotezi (EPH) özelliklerine sahip olmadığı ve zaman kiralama bedeli değerlerinin geçmiş değerleriyle aralarında bir bağlantı olduğu tespit edilmiştir. Bu durum, geçmiş verilerin ve bazı stratejilerin kullanılarak olağanüstü karlar elde edilebilmesini mümkün kllmaktadır. 


\section{Introduction}

There is a strong relationship between the energy demand and the economic growth [1], and the world economy fundamentally depends on fossil fuel energy resources such as coal, oil and natural gas. The share of these three main fossil fuel types in total consumption are about 30\% for each. This great share of oil is very important in world economy since, in addition to its importance in electricity production and household heating, the main source of energy for transportation is oil. The economy needs transportation for the move of raw materials, final products, people and information [2].

Pipelines, tanker ships and land vehicles are generally used for transportation of oil. Tankers and pipelines are more economical options among them. Especially tanker shipping provides an economical and sufficient way to transport liquid bulk even compare to pipeline for long distance international and cross-continental seaborne trade[3]. Also, in some cases, dirty tankers are used as floating storage in order to store crude oil.

The maritime industry consists of two main markets; namely dry cargo and liquid cargo markets. These basic markets are also divided into sub markets; like dry cargo market is divided into two; General cargo markets and dry bulk markets. General cargo market is also divided into two; Break bulk markets and container markets. Liquid market which is our topic in this article is divided into two; Crude oil market and product market, but product market is also divided into two as dirty and clean markets. General definition of dirty market is also used for the crude oil, heavy fuel oil and unrefined condensates [3]. Like all others, crude oil market contains four closely related markets which are the freight (chartering the vessel by voyage or time charter basis, as well as chartering the bigger tonnage like Suezmax and VLCC for floating storage facilities especially passing last 2-3 years), sale and purchase, newbuilding and demolition markets. The freight market trades in sea transport to earn freight income; the sale and purchase market trades second-hand ships; the newbuilding market trades newly built ships; and the demolition market deals in ships for scrapping and recycling [4]. This study is interested in testing the Efficient Market Hypothesis (EMH) in the dirty freight market.

EMH which is the cornerstone of the modern finance theory was originally introduced by Fama [5]. An efficient market means that all information is instantly distributed on the market and there is no distortion in this system [6]. In other words, the prices on the market should contain all the information. Conventionally, the efficient market hypothesis may take on three forms; (1) If the current price incorporates all information in past prices, it is called weak form; (2) if the current price incorporates all publicly available information, it is called semi-strong form; or (3) if the current price incorporates all information, including private information, it is called strong form. [7]. In efficient markets, technical trading rules based on historical data cannot yield excess profits [8]. Because in such a market prices move randomly. In this respect, it is crucial for the market to have an efficient structure to provide a fair competitive environment for investors and stakeholders.

Freight rates used in transportation activities cannot be traded and stored. Therefore, the efficient market hypothesis in the traditional form cannot be used at freight rates. However, according to Adland and Strandenes [7], the concept of efficient market hypothesis can still be applied in the freight market. In this direction, the efficient market hypothesis in earnings of VLCC, Suezmax and Aframax vessels which are carrying out their operations in the 


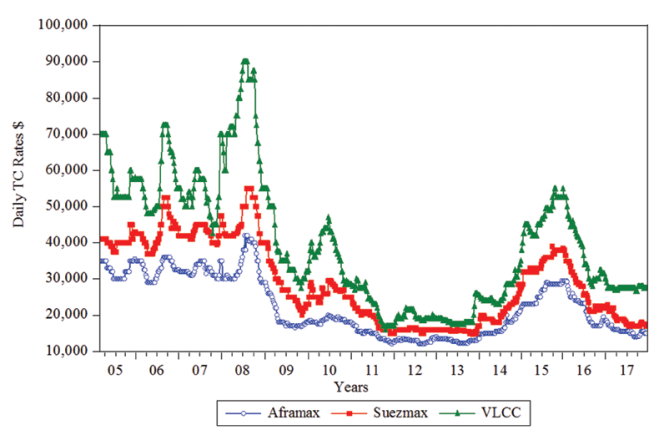

Figure 1. Graphical Display of the One Year Time Charter Rates

crude market was tested by using their daily rate of one-year time charter hire earnings.

Figure 1 presents the daily values of the one-year time charter rates for Aframax, Suezmax and VLCC tanker markets covering the years 2005 and 2017 based on weekly observations [9]. For example, in the VLCC market, even though rates peaked at around $\$ 90,000$ on boom periods, they fell to as low as $\$ 16,000$ during the collapse periods. When these extreme values are considered, estimating future values by looking at the past prices gives some stakeholders extraordinary returns. In this respect, the fact that the markets have an efficient structure contributes to a fair competitive environment.

This paper contributes to the literature by proposing an alternative test of market efficiency in the tanker freight market. The BDS Independence Test, designed by Brock, Dechert and Scheinkman [10], was used in this study to measure the randomness of the series. As a result of the study, it was determined that despite the structural differences between the tested markets, they did not have efficient market hypothesis characteristics.

The content of the study is organized as follows; in the literature review section, previous similar studies are examined and this study is positioned within them; in the methodology section, method and data set used in the study are introduced; in the findings section, results of the econometric analysis are presented; and lastly in the conclusion and discussion section, the findings of the study are evaluated and some proposals are presented to policy makers and stakeholders in the industry.

\section{Literature Review}

The efficient market hypothesis is not very popular in the maritime literature, but it is seen that the freight market and the sale and purchase market have been studied in general. Adland and Koekebakker [8] test the validity of the efficient market hypothesis in the sale and purchase market for bulk ships. They find that except some lower segments, sale and purchase market doesn't offer chance for excess profits. Same market is also investigated by Alizadeh and Nomikos [11]. They use some technical rules and find that these strategies are helping to generate excess profits. On the other hand, one of the studies that examines EMH in freight market is investigated by Tsioumas and Papadimitrou [12]. They have analyzed trip charter rates and time charter rates by implementing some trading strategies and they have found that following technical rules is helping to make excess profits. Another study by Nomikos and Doctor [13] shows that FFA markets can't have the characteristics of efficient market hypothesis as well. The investigation of the efficient market hypothesis in the tanker market subject to this study is also examined by the Adland and Stradenes [7]. They analyze past spot prices by technical methods and develop strategies. As a result they find that can make profits by using these techniques which are based on historical spot prices.

In addition to these, the efficient market hypothesis in the dry bulk market has been examined by the authors of the current study by several methods including the BDS independence test. Baltic Dry Index (BDI) has been used as a representative of dry 
bulk freight earnings and as a result it has been found that BDI doesn't follow random walk. In other words, there have been a dependence between the index and its past values, indicating that future values could be estimated using past values and market has not been efficient in weak form [14]. As suggested at the end of that study, the same test has been also applied in this study to test $\mathrm{EMH}$ in the dirty tanker market.

This paper has been expected to contribute to the literature by proposing an alternative test of market efficiency in the tanker freight market. In the next section, the method and data used in the study have been introduced.

\section{Methodology}

There are many ways to test non-linear structures in time series. These tests are generally divided into two groups; general tests and special tests. General tests are used to determine deviations from the randomness in the data [15]. Among these tests, the BDS Independence Test, designed by Brock, Dechert and Scheinkman[10], has been used in this study to measure the randomness of the series.

The BDS test is applied to residuals of an estimated series of and checks whether the residuals are independent and identically distributed. The null hypothesis for this test implies that the data in a time series is independent and identically distributed [16]. Rejection of null hypothesis means that residuals contain some hidden, possibly non-linear structure in consequence of inefficient market.

For this purpose, Eviews 10 which is widely used and accepted econometric software has been used in this study. Firstly, Aframax, Suezmax and VLCC time charter values were converted into return series using the equation (1) below.

$$
R_{\text {TCRATE }}=\ln \left(\text { TCRATE }_{t}\right)-\ln \left(\text { TCRATE }_{t-1}\right)
$$

where;

TCRATE $_{t}$ is value of the related charter rate on week $t$

TCRATE $_{t-1}$ is value of the related charter rate on week $t$-1

After getting the return series for all variables, ARMA models which have the lowest value of Akaike were selected for each series using Automatic ARIMA function of the software. Then, the three proposed models were estimated and the residuals were extracted. This method also helps to improve the results of the analysis by reducing the variance studied. Lastly BDS Independence tests were applied to the residuals of each series in order to determine whether there were dependencies between residual values or not.

\subsection{Data}

Tanker types used in transporting crude oil are Handymax $(<50,000 \mathrm{dwt})$, Panamax $(50,000-80,000 \mathrm{dwt})$, Aframax $(80,000-$ $120,000 \mathrm{dwt})$, Suezmax (120,000-200,000 dwt), VLCC (200,000-320,000 dwt) and ULCC $(>320,000 \mathrm{dwt})$ in general [17]. In terms of accessibility to the data, the types subject to this study are Aframax, Suezmax and VLCC.

Descriptive statistics of the dataset used are shown in Table 1 . The data covers the dates between 23rd February 2005 and 20th December 2017 on a weekly basis and consists of 663 observations. All of the return series are not normally distributed according to the Jarque-Bera statistic. Also when the Kurtosis and Skewness values of the return series are examined, it can be seen that the data are skewed and the tail effects are excessive. Additionally, for Suezmax and VLCC charter rates, skewness values are positive but negative for Aframax charter rates. The fact that a positive value indicates that the market is more influenced by positive news, while the negative value indicates the opposite 
Table 1. Descriptive Statistics for Variables

\begin{tabular}{|l|l|l|l|l|l|l|l|l|l|}
\hline & AFRAM. & SUEZM. & VLCC & R. AFRA & R. SUEZ & R. VLCC & RES. AF. & RES. SU. & RES. VL. \\
\hline Mean & 22274.43 & 29026.02 & 9763.57 & -0.001280 & -0.001330 & -0.001411 & $-7.41 \mathrm{E}-06$ & $1.31 \mathrm{E}-08$ & $1.33 \mathrm{E}-05$ \\
\hline Median & 8750.00 & 6500.00 & 5000.00 & 0.000000 & 0.000000 & 0.000000 & 0.000836 & 0.001039 & 0.000957 \\
\hline Maximum & 2000.00 & 5000.00 & 0000.00 & 0.121361 & 0.131028 & 0.287682 & 0.115801 & 0.120015 & 0.275475 \\
\hline Minimum & 2000.00 & 4750.00 & 6000.00 & -0.154151 & -0.111226 & -0.125163 & -0.156628 & -0.104010 & -0.110047 \\
\hline Std. Dev. & 211.199 & 1157.25 & 7703.44 & 0.023899 & 0.027528 & 0.033541 & 0.023023 & 0.026441 & 0.031846 \\
\hline Skewness & .461638 & .386504 & .684717 & -0.230261 & 0.683766 & 1.397020 & -0.375987 & 0.551844 & 1.349160 \\
\hline Kurtosis & .810227 & .847791 & .753769 & 10.70107 & 9.372349 & 14.36803 & 11.14114 & 8.325288 & 13.71446 \\
\hline Jarque-Bera & 2.65348 & 3.18169 & 3.48143 & 1641.718 & 1171.657 & 3779.984 & 1843.768 & 815.8272 & 3367.387 \\
\hline Probability & .000000 & .000000 & .000000 & 0.000000 & 0.000000 & 0.000000 & 0.000000 & 0.000000 & 0.000000 \\
\hline Observations & 663 & 663 & 663 & 662 & 662 & 662 & 662 & 662 \\
\hline $\begin{array}{l}\text { Std.Dv./ } \\
\text { Mean }\end{array}$ & $37 \%$ & $38 \%$ & $45 \%$ & & & & & 662 \\
\hline
\end{tabular}

Source: Fearnley Review

situation. This means that the Aframax market has different characteristics than the other two markets. The last row of the table contains values showing the volatility of the markets, and according to this table, the riskiest market is the VLCC market with $45 \%$. Aframax is relatively less risky market (37\%) since mainly operated in short and medium distances in Continental and MediterraneanEurope, West Africa, US Gulf and Far East.

When the movements of the three markets involved in the study were examined, it was obvious that there were significant correlations between them in the positive direction because of the fact that they are naturally in the same market. Table 2 shows both Pearson's and Spearman's correlations coefficients. The directions of movement are in the same direction, but the reactions they give to macroeconomic events are different as deduced from the skewness values.
Table 2. The Results of the Correlation Analysis

\begin{tabular}{|c|c|c|c|c|}
\hline \multirow{2}{*}{\multicolumn{2}{|c|}{$\begin{array}{l}\text { (t statistics) } \\
\text { Probabilities }\end{array}$}} & \multicolumn{3}{|c|}{ Pearson's Correlation } \\
\hline & & R AFRA & R SUEZ & R VLCC \\
\hline \multirow{9}{*}{ 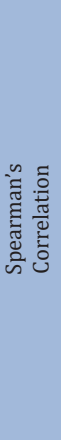 } & \multirow{3}{*}{$\begin{array}{c}\mathbf{R} \\
\text { AFRA }\end{array}$} & 1.000000 & 0.398479 & 0.420371 \\
\hline & & ----- & (11.16155) & (11.90226) \\
\hline & & ----- & 0.0000 & 0.0000 \\
\hline & \multirow{3}{*}{$\begin{array}{c}\text { R } \\
\text { SUEZ }\end{array}$} & 0.404510 & 1.000000 & 0.470585 \\
\hline & & (11.36321) & ----- & (13.70147) \\
\hline & & 0.0000 & ----- & 0.0000 \\
\hline & \multirow{3}{*}{$\begin{array}{c}\text { R } \\
\text { VLCC }\end{array}$} & 0.436240 & 0.427833 & 1.000000 \\
\hline & & (12.45481) & (12.16036) & ---- \\
\hline & & 0.0000 & 0.0000 & ---- \\
\hline
\end{tabular}

In the next step, the BDS Independence test was implemented along with the Findings section in order to check whether three submarkets under the same market have efficient market characteristics or not. 


\section{Findings}

The findings section was first initiated by selecting the most appropriate ARMA models for the return series of Aframax, Suezmax and VLCC time charter rate values. For this purpose, the optimal model for each variable was determined by using the automatic ARIMA forecasting function in the econometric software. In Attachment 1 , the return series of each variable and the figures of the most appropriate model values are presented. Models that offer the lowest Akaike Information Criteria value were selected. At the analysis interface, the maximum AR and MA values were selected as 12 , and the maximum difference value was selected as 0 .

After analysis for each variable was completed, for Aframax, the $\operatorname{ARMA}(5,4)$ model, which provides Akaike value of -4.672, was selected. For Suezmax, the ARMA $(9,12)$ model with a Akaike value of -4.374 was selected. Lastly for VLCC, the ARMA $(5,5)$ model which has -4.008 Akaike value was selected. After the optimal models for each variable were determined, the next step was the estimation of ARMA equations.

The determined ARMA $(5,4)$ model was estimated for Aframax and the results were presented in Attachment 2.At this point, the individual significance of the variables does not mean much, and it is more important that the model is meaningful as a whole. $\mathrm{F}$ test shows the significance of the model as a whole, and as seen in Attachment 2, the model established for Aframax is significant $(\mathrm{p}<0.05)$. Another important point is that $\mathrm{AR}$ and MA roots should be smaller than 1 . When all the indicators in the table were examined, it was seen that all of the roots meet this necessity.

The estimation results of the ARMA $(9,12)$ model for Suezmax were shown in Attachment 3. When the F test and the AR and MA roots were examined, it was seen that the model was significant as a whole $(p<0.05)$ and the roots were smaller than 1 .

Finally, the ARMA $(5,5)$ model for the VLCC was estimated and the results were presented in Attachment 4. The established model was significant as a whole and the all roots were less than 1 . As a result, all ARMA models were found to be utilizable for further analysis. In the next process, residuals were separated from the 3 established models and the BDS analysis was implemented.

Graphical display of residuals separated from ARMA models were presented in Figure 2. Volatility is most commonly encountered in the Suezmax data set, and VLCC is the least volatile one. This situation can be interpreted as the fact that EMH is stronger in the Suezmax market.

Then the Fraction of Pairs method was chosen and 6 was selected as the maximum DIM from the software interface. Also Bootstrap option was used by selecting 1000 repetitions. The results of the BDS test are shown in Table 3. Independence was rejected in all dimensions of all
RESDG.AFRA

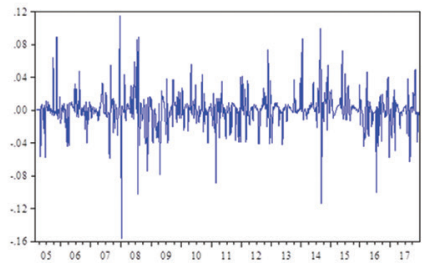

RESDGSUEZ

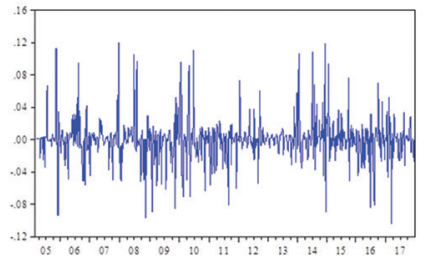

RESIDGVLCC

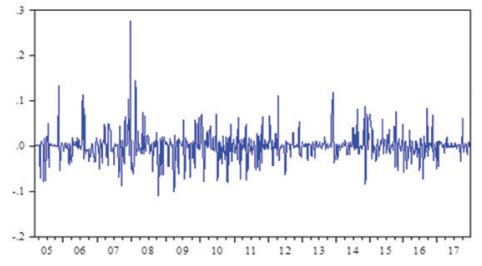

Figure 2. Residuals of ARIMA Models 
Table 3. BDS Independence Test Results

\begin{tabular}{|c|c|c|c|c|c|c|}
\hline Markets & Dimension & BDS Statistic & Std. Error & z-Statistic & $\begin{array}{l}\text { Normal } \\
\text { Prob. }\end{array}$ & $\begin{array}{c}\text { Bootstrap } \\
\text { Prob. }\end{array}$ \\
\hline \multirow{5}{*}{ AFRAMAX } & 2 & 0.015454 & 0.004916 & 3.143507 & 0.0017 & 0.0040 \\
\hline & 3 & 0.027535 & 0.007856 & 3.505104 & 0.0005 & 0.0000 \\
\hline & 4 & 0.035906 & 0.009412 & 3.814833 & 0.0001 & 0.0000 \\
\hline & 5 & 0.033761 & 0.009874 & 3.419183 & 0.0006 & 0.0020 \\
\hline & 6 & 0.031553 & 0.009586 & 3.291427 & 0.0010 & 0.0060 \\
\hline \multirow{5}{*}{ SUEZMAX } & 2 & 0.010848 & 0.004944 & 2.194116 & 0.0282 & 0.0500 \\
\hline & 3 & 0.016058 & 0.007882 & 2.037340 & 0.0416 & 0.0580 \\
\hline & 4 & 0.022723 & 0.009421 & 2.411922 & 0.0159 & 0.0220 \\
\hline & 5 & 0.026598 & 0.009860 & 2.697591 & 0.0070 & 0.0080 \\
\hline & 6 & 0.027396 & 0.009550 & 2.868643 & 0.0041 & 0.0040 \\
\hline \multirow{5}{*}{ VLCC } & 2 & 0.021551 & 0.004645 & 4.639571 & 0.0000 & 0.0000 \\
\hline & 3 & 0.033154 & 0.007403 & 4.478434 & 0.0000 & 0.0000 \\
\hline & 4 & 0.040548 & 0.008846 & 4.583757 & 0.0000 & 0.0000 \\
\hline & 5 & 0.042797 & 0.009254 & 4.624483 & 0.0000 & 0.0000 \\
\hline & & 0.041764 & 0.008960 & 4.661392 & 0.0000 & 0.0000 \\
\hline
\end{tabular}

markets according to normal probabilities. According to the bootstrap probabilities, independence for all markets was rejected once again, but the probabilities of the Suezmax market were close to the critical values. But their rejection did not constitute major problems in terms of the reliability of the results of the test. As a result, the tanker market consisting of Aframax, Suezmax and VLCC markets were not efficient in the weak form.

\section{Conclusion}

Raw materials, final products, people and information need transportation for economic and social activities [2]. There are many modes of transport for this requirements and sea transport is one of the most utilized modes within them since it is the most economical mode for long range transportation of big lots of cargoes which has low value. Like other modes of transport, the demand for sea transport is a derived-demand from international trade. So, transport service providers do not have significant control power and influence over this demand [18].Also free and fair competition rules is valid and effective in the market, since one or two ship owners cannot dominate the market with their tonnage supply. As well as current and valid antitrust law does not permit this kind of applications. Freight occurs in the market under full competition rules. Due to these reasons, freight revenues are vital for shipowners and the return on investment in ships relies on seaborne trade volume [4], especially in the tanker market, which is known as a capital intensive industry [19]. At this point, a random walk of freight rates contributes to ensuring a fair competitive environment for relatively small investors. 
This can be achieved through market efficiency.

In this study, it was tested whether the daily values of 1-year time charter hiring rates of the Aframax, Suezmax and VLCC ship types, which have important share in the tanker market, are efficient or not. Previously, freight markets have been examined in the literature and the results have shown that freight markets are not efficient $[12,13,7]$.EMH was also tested by us with BDS test in dry bulk market, and it was found that there were dependencies between past values of the Baltic Dry Index which was an indication of inefficient market conditions [14].

This paper was expected to contribute to the literature by proposing an alternative test (BDS Independence Test) of market efficiency in the tanker freight market and it plays a complementary role.As a result of the analyzes carried out, it was determined that time charter rates of the all three markets had dependencies between their past values and the markets did not have EMH characteristics in the weak form. Thanks to this dependence, it can be said that technical and commercial rules or strategies can be followed to achieve excess profits in the tanker market.

The most important limitation of the study is that data has been compiled from 663 free reports and consists of weekly observations. Even though the time charter rates are not instantly variable values, it may be more useful to use the daily frequency. Further studies may generate trading scenarios in the freight market and test excess profitability based on the results of different econometric methods. Also as investigated by Skewness values of the series in the data section, different structure of Aframax market can be analyzed.

\section{References}

[1] Kuleyin, B., \& Cerit, A. G. (2017). Turkish Seaborne Trade and The
Effects of the Strategic Developments in The International Energy and Transport Corridors; A Qualitative Research. Journal of ETA Maritime Science, 5(2): 120-138.

[2] Carmalt, S. W. (2017). The Economics of Oil: A Primer Including Geology, Energy, Economics, Politics. Springer.

[3] Lun, Y. V., Hilmola, O. P.,Goulielmos, A. M., Lai, K. H. and Cheng, T. E. (2012). Oil Transport Management. Springer Science \& Business Media.

[4] Stopford, M. (2009). Maritime Economics. Routledge, New York

[5] Fama, E. F. (1970). Efficient Capital Markets: A Review of Theory and Empirical Work. Journal of Finance, 25(2): 373-417.

[6] Engelen, S., Dullaert, W.andVernimmen, B. (2009). Market Efficiency within Dry Bulk Markets in The Short Run: A Multi-Agent System Dynamics Nash Equilibrium. Maritime Policy \& Management: The Flagship Journal of International Shipping and Port Research, 36(5): 385-396.

[7] Adland, R.and Strandenes, S. (2006). Market Efficiency in The Bulk Freight Market Revisited.Maritime Policy \& Management: The Flagship Journal of International Shipping and Port Research, 33(2): 107-117.

[8] Adland, R. amdKoekebakker, S. (2004). Market Efficiency in the Second-hand Market for Bulk Ships. Maritime Economics \& Logistics, 6: 1-15.

[9] Fearnley Weekly Review. (2018). 1 Year Time Charter Earnings. Access Date: 20.02.2018, https://www. fearnleys.com/weekly-research.

[10] Brock, W. A., Dechert, W. D. and Scheinkman, J. A. (1987). A Test for Independence Based On the Correlation Dimension, Manuscript, Social Systems Research Unit, University of Wisconsin. 
[11] Alizadeh, A. H., and N. K. Nomikos. 2007. Investment Timing and Trading Strategies in the Sale and Purchase Market for Ships.Transportation Research Part B: Methodological, 41(1): 126-143.

[12] Tsioumas, V. and Papadimitriou, S. (2015). Excess Returns in The Spot Market for Bulk Carriers. Maritime Economics \& Logistics, 17(4): 399415.

[13] Nomikos, N. and K. Doctor. (2013). Market Timing Strategies in the Freight Derivatives Market.Transportation Research Part E: Logistics and Transportation Review, 52: 77-93.

[14] Açık, A. and Başer, S. Ö. (2018). Is Baltic Dry Index Efficient?.Journal of Yasar University, 13(50):140-149.

[15] Brooks, C. (2014). Introductory Econometrics for Finance. Cambridge University Press.

[16] Broock, W. A., Scheinkman, J. A., Dechert, W. D. and LeBaron, B.(1996). A Test for Independence Based on the Correlation Dimension.Econometric Reviews, August, 15(3): 197-235.

[17] Plunkett, J. W. (2010). Plunkett's Transportation, Supply Chain \& Logistics Industry Almanac 2010. Plunkett Research, Ltd.

[18] McConville, J. (1999). Economics of Maritime Transport: Theory and Practice. Witherby, London

[19] Chen, Y. S and Wang, S. T. (2004). The Empirical Evidence of the Leverage Effect On Volatility in International Bulk Shipping Market. Maritime Policy Management, 31(2):109-124. 
Attachment Figure 1. Graphical Display of Return Series and Their Best ARMA Models
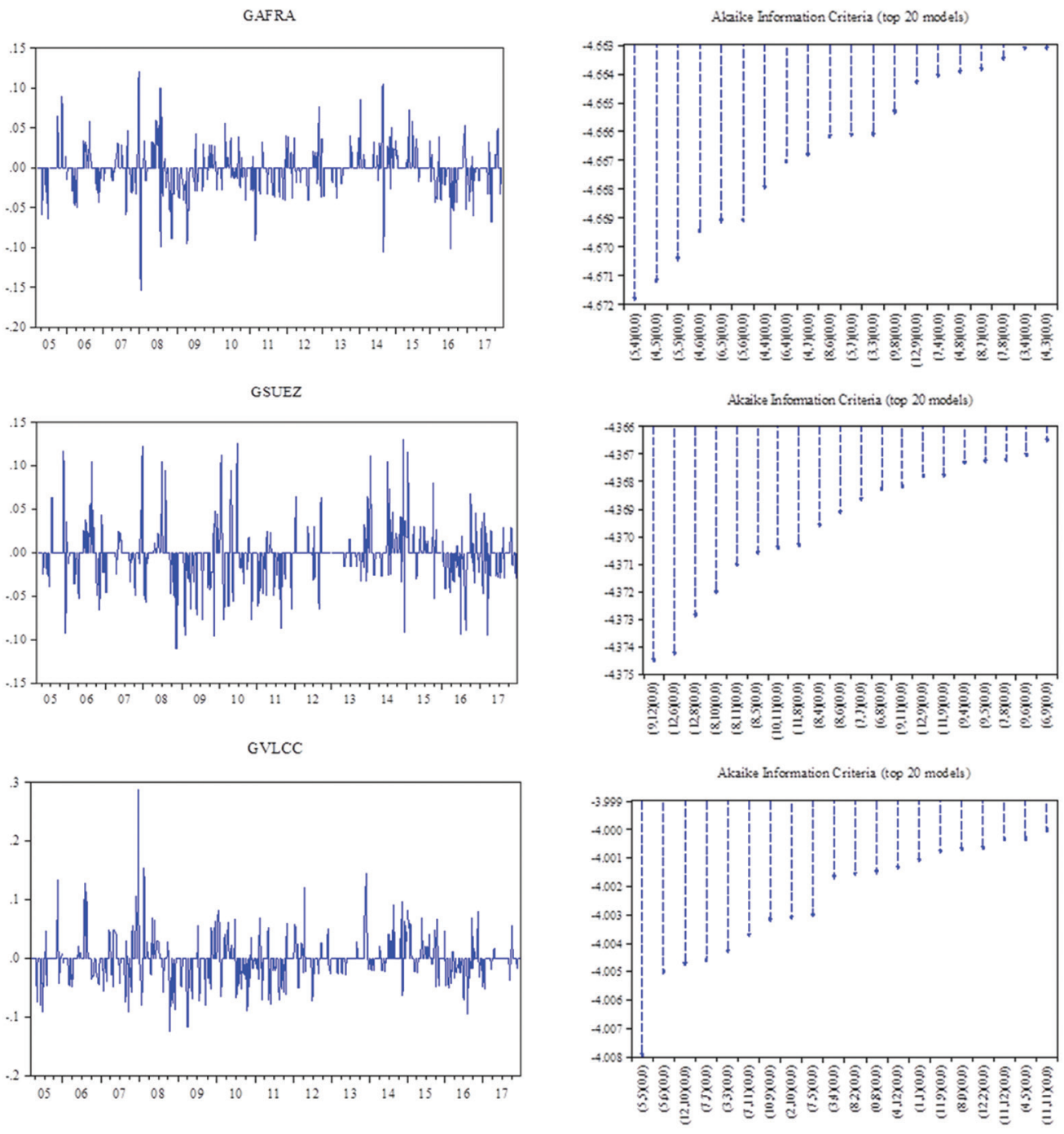
Attachment Table 1. ARMA $(5,4)$ Model Estimation Results of AFRAMAX

\begin{tabular}{|c|c|c|c|c|}
\hline \multicolumn{5}{|c|}{ Dependent Variable: R AFRA } \\
\hline \multicolumn{5}{|c|}{ Method: ARMA Maximum Likelihood (OPG - BHHH) } \\
\hline \multicolumn{5}{|c|}{ Sample: $3 / 02 / 200512 / 20 / 2017$} \\
\hline \multicolumn{5}{|c|}{ Included observations: 662} \\
\hline \multicolumn{5}{|c|}{ Convergence achieved after 47 iterations } \\
\hline \multicolumn{5}{|c|}{ Coefficient covariance computed using outer product of gradients } \\
\hline Variable & Coefficient & Std. Error & t-Statistic & Prob. \\
\hline $\mathrm{C}$ & -0.001298 & 0.001391 & -0.933399 & 0.3510 \\
\hline $\operatorname{AR}(1)$ & 0.768444 & 0.086444 & 8.889533 & 0.0000 \\
\hline $\mathrm{AR}(2)$ & 0.342337 & 0.105220 & 3.253533 & 0.0012 \\
\hline $\operatorname{AR}(3)$ & 0.430813 & 0.146578 & 2.939138 & 0.0034 \\
\hline $\mathrm{AR}(4)$ & -0.839491 & 0.070930 & -11.83554 & 0.0000 \\
\hline $\mathrm{AR}(5)$ & 0.098931 & 0.045485 & 2.175057 & 0.0300 \\
\hline $\mathrm{MA}(1)$ & -0.735464 & 0.088678 & -8.293667 & 0.0000 \\
\hline $\mathrm{MA}(2)$ & -0.267561 & 0.106194 & -2.519535 & 0.0120 \\
\hline MA(3) & -0.498695 & 0.138480 & -3.601211 & 0.0003 \\
\hline $\operatorname{MA}(4)$ & 0.789317 & 0.088074 & 8.961948 & 0.0000 \\
\hline SIGMASQ & 0.000529 & $1.60 \mathrm{E}-05$ & 33.17569 & 0.0000 \\
\hline R-squared & 0.072036 & \multicolumn{2}{|c|}{ Mean dependent var } & -0.001280 \\
\hline $\begin{array}{l}\text { Adjusted } \\
\text { R-squared }\end{array}$ & 0.057781 & \multicolumn{2}{|c|}{ S.D. dependent var } & 0.023899 \\
\hline S.E. of regression & 0.023199 & \multicolumn{2}{|c|}{ Akaike info criterion } & -4.671797 \\
\hline Sum squared resid & 0.350354 & \multicolumn{2}{|c|}{ Schwarz criterion } & -4.597103 \\
\hline Log likelihood & 1557.365 & \multicolumn{2}{|c|}{ Hannan-Quinn criter. } & -4.642849 \\
\hline F-statistic & 5.053550 & \multicolumn{2}{|c|}{ Durbin-Watson stat } & 2.004616 \\
\hline Prob(F-statistic) & 0.000000 & & & \\
\hline \multirow[t]{2}{*}{ Inverted AR Roots } & $.92-.26 \mathrm{i}$ & $.92+.26 \mathrm{i}$ & .13 & $-.60+.71 i$ \\
\hline & $-.60-.71 \mathrm{i}$ & & & \\
\hline Inverted MA Roots & $.92+.30 \mathrm{i}$ & $.92-.30 \mathrm{i}$ & $-.55+.73 \mathrm{i}$ & $-.55-.73 \mathrm{i}$ \\
\hline
\end{tabular}


Attachment Table 2. ARMA $(9,12)$ Model Estimation Results of SUEZMAX

\begin{tabular}{|c|c|c|c|c|}
\hline \multicolumn{5}{|c|}{ Dependent Variable: GSUEX } \\
\hline \multicolumn{5}{|c|}{ Method: ARMA Maximum Likelihood (OPG - BHHH) } \\
\hline \multicolumn{5}{|c|}{ Sample: 3/02/2005 12/20/2017 } \\
\hline \multicolumn{5}{|c|}{ Included observations: 662} \\
\hline \multicolumn{5}{|c|}{ Convergence not achieved after 500 iterations } \\
\hline \multicolumn{5}{|c|}{ Coefficient covariance computed using outer product of gradients } \\
\hline Variable & Coefficient & Std. Error & t-Statistic & Prob. \\
\hline $\mathrm{C}$ & -0.001352 & 0.001845 & -0.732708 & 0.4640 \\
\hline $\operatorname{AR}(1)$ & -0.465084 & 0.348449 & -1.334728 & 0.1824 \\
\hline $\mathrm{AR}(2)$ & 0.014954 & 0.257982 & 0.057966 & 0.9538 \\
\hline $\mathrm{AR}(3)$ & -0.491476 & 0.275292 & -1.785288 & 0.0747 \\
\hline $\operatorname{AR}(4)$ & -0.453668 & 0.275083 & -1.649208 & 0.0996 \\
\hline $\mathrm{AR}(5)$ & -0.053469 & 0.296990 & -0.180036 & 0.8572 \\
\hline $\operatorname{AR}(6)$ & 0.199441 & 0.244852 & 0.814535 & 0.4156 \\
\hline $\mathrm{AR}(7)$ & -0.335028 & 0.215883 & -1.551899 & 0.1212 \\
\hline $\mathrm{AR}(8)$ & 0.341593 & 0.263525 & 1.296245 & 0.1954 \\
\hline $\mathrm{AR}(9)$ & 0.620961 & 0.217514 & 2.854804 & 0.0044 \\
\hline MA(1) & 0.523372 & 0.355471 & 1.472333 & 0.1414 \\
\hline $\mathrm{MA}(2)$ & 0.091804 & 0.270238 & 0.339713 & 0.7342 \\
\hline $\mathrm{MA}(3)$ & 0.560034 & 0.289507 & 1.934441 & 0.0535 \\
\hline $\mathrm{MA}(4)$ & 0.617853 & 0.296872 & 2.081210 & 0.0378 \\
\hline $\mathrm{MA}(5)$ & 0.176273 & 0.367831 & 0.479224 & 0.6319 \\
\hline MA(6) & -0.080770 & 0.309685 & -0.260813 & 0.7943 \\
\hline $\operatorname{MA}(7)$ & 0.441687 & 0.293895 & 1.502875 & 0.1334 \\
\hline MA(8) & -0.174786 & 0.346007 & -0.505152 & 0.6136 \\
\hline $\mathrm{MA}(9)$ & -0.581559 & 0.234560 & -2.479368 & 0.0134 \\
\hline $\operatorname{MA}(10)$ & -0.039891 & 0.084664 & -0.471166 & 0.6377 \\
\hline MA(11) & 0.043004 & 0.086279 & 0.498432 & 0.6184 \\
\hline $\operatorname{MA}(12)$ & -0.020099 & 0.070011 & -0.287087 & 0.7741 \\
\hline SIGMASQ & 0.000698 & 4.30E-05 & 16.25049 & 0.0000 \\
\hline R-squared & 0.077456 & \multicolumn{2}{|l|}{ Mean dependent var } & -0.001330 \\
\hline Adjusted R-squared & 0.045694 & \multicolumn{2}{|l|}{ S.D. dependent var } & 0.027528 \\
\hline S.E. of regression & 0.026892 & \multicolumn{2}{|l|}{ Akaike info criterion } & -4.352852 \\
\hline Sum squared resid & 0.462106 & \multicolumn{2}{|l|}{ Schwarz criterion } & -4.196672 \\
\hline Log likelihood & 1463.794 & \multicolumn{2}{|l|}{ Hannan-Quinn criter. } & -4.292324 \\
\hline F-statistic & 2.438640 & \multicolumn{2}{|l|}{ Durbin-Watson stat } & 1.999880 \\
\hline Prob(F-statistic) & 0.000283 & & & \\
\hline \multirow[t]{3}{*}{ Inverted AR Roots } & .85 & $.69-.72 \mathrm{i}$ & $.69+.72 \mathrm{i}$ & $.19-.94 \mathrm{i}$ \\
\hline & $.19+.94 \mathrm{i}$ & $-.64-.75 \mathrm{i}$ & $-.64+.75 i$ & $-.90-.08 \mathrm{i}$ \\
\hline & $-.90+.08 \mathrm{i}$ & & & \\
\hline \multirow[t]{3}{*}{ Inverted MA Roots } & .77 & $.70-.72 \mathrm{i}$ & $.70+.72 \mathrm{i}$ & $.20+.94 \mathrm{i}$ \\
\hline & $.20-.94 \mathrm{i}$ & $.18+.22 \mathrm{i}$ & $.18-.22 \mathrm{i}$ & -.54 \\
\hline & $-.63+.76 \mathrm{i}$ & $-.63-.76 \mathrm{i}$ & $-.82-.06 \mathrm{i}$ & $-.82+.06 \mathrm{i}$ \\
\hline
\end{tabular}


Attachment Table 3. ARMA (5, 5) Model Estimation Results of VLCC

\begin{tabular}{|c|c|c|c|c|}
\hline \multicolumn{5}{|c|}{ Dependent Variable: GVLCC } \\
\hline \multicolumn{5}{|c|}{ Method: ARMA Maximum Likelihood (OPG - BHHH) } \\
\hline \multicolumn{5}{|c|}{ Sample: 3/02/2005 12/20/2017 } \\
\hline \multicolumn{5}{|c|}{ Included observations: 662} \\
\hline \multicolumn{5}{|c|}{ Failure to improve objective (singular hessian) after 423 iterations } \\
\hline \multicolumn{5}{|c|}{ Coefficient covariance computed using outer product of gradients } \\
\hline Variable & Coefficient & Std. Error & t-Statistic & Prob. \\
\hline $\mathrm{C}$ & -0.001424 & 0.002445 & -0.582681 & 0.5603 \\
\hline $\operatorname{AR}(1)$ & -0.157599 & 0.093441 & -1.686613 & 0.0922 \\
\hline $\mathrm{AR}(2)$ & 0.173959 & 0.086626 & 2.008151 & 0.0450 \\
\hline $\mathrm{AR}(3)$ & -0.433293 & 0.054600 & -7.935761 & 0.0000 \\
\hline $\mathrm{AR}(4)$ & -0.162300 & 0.080549 & -2.014917 & 0.0443 \\
\hline $\mathrm{AR}(5)$ & 0.755225 & 0.080550 & 9.375833 & 0.0000 \\
\hline MA(1) & 0.321178 & 6.156482 & 0.052169 & 0.9584 \\
\hline $\mathrm{MA}(2)$ & -0.011202 & 2.909526 & -0.003850 & 0.9969 \\
\hline $\mathrm{MA}(3)$ & 0.539599 & 0.187629 & 2.875884 & 0.0042 \\
\hline $\mathrm{MA}(4)$ & 0.306491 & 7.197334 & 0.042584 & 0.9660 \\
\hline $\mathrm{MA}(5)$ & -0.687484 & 9.220220 & -0.074563 & 0.9406 \\
\hline SIGMASQ & 0.001013 & 0.002814 & 0.359803 & 0.7191 \\
\hline R-squared & 0.098520 & \multicolumn{2}{|c|}{ Mean dependent var } & -0.001411 \\
\hline $\begin{array}{l}\text { Adjusted } \\
\text { R-squared }\end{array}$ & 0.083264 & \multicolumn{2}{|c|}{ S.D. dependent var } & 0.033541 \\
\hline S.E. of regression & 0.032114 & \multicolumn{2}{|c|}{ Akaike info criterion } & -4.008003 \\
\hline Sum squared resid & 0.670368 & \multicolumn{2}{|c|}{ Schwarz criterion } & -3.926518 \\
\hline Log likelihood & 1338.649 & \multicolumn{2}{|c|}{ Hannan-Quinn criter. } & -3.976423 \\
\hline F-statistic & 6.457874 & \multicolumn{2}{|c|}{ Durbin-Watson stat } & 2.011635 \\
\hline Prob(F-statistic) & 0.000000 & & & \\
\hline \multirow[t]{2}{*}{ Inverted AR Roots } & .82 & $.38+.91 \mathrm{i}$ & $.38-.91 \mathrm{i}$ & $-.86-.46 \mathrm{i}$ \\
\hline & $-.86+.46 \mathrm{i}$ & & & \\
\hline \multirow[t]{2}{*}{ Inverted MA Roots } & .69 & $.37+.93 i$ & $.37-.93 \mathrm{i}$ & $-.88-.48 \mathrm{i}$ \\
\hline & $-.88+.48 \mathrm{i}$ & & & \\
\hline
\end{tabular}

